\title{
“NGOs” Defending Migrant Workers’ Rights
}

Semi-union organisations contribute to the regime's dynamic stability

\section{Chloé Froissart}

Translator. N. Jayaram

\section{OpenEdition}

\section{Journals}

\section{Electronic version}

URL: http://journals.openedition.org/chinaperspectives/5549

DOI: 10.4000/chinaperspectives.5549

ISSN: 1996-4617

\section{Publisher}

Centre d'étude français sur la Chine contemporaine

\section{Printed version}

Date of publication: 30 July 2011

Number of pages: $18-25$

ISSN: 2070-3449

\section{Electronic reference}

Chloé Froissart, «"NGOs" Defending Migrant Workers' Rights », China Perspectives [Online], 2011/2 |

2011, Online since 30 June 2014, connection on 28 October 2019. URL : http://

journals.openedition.org/chinaperspectives/5549; DOI : 10.4000/chinaperspectives.5549 


\title{
"NGOs" Defending
}

\section{Migrant Workers' Rights}

\section{Semi-union organisations contribute to the regime's dynamic stability}

\section{CHLOÉ FROISSART*}

\begin{abstract}
In the absence of trade union freedoms, "NG0s" have emerged to defend migrant workers' rights. This article takes a close look at the mobilisation of such organisations, assesses their short-term impact, and examines their role in China's political system. NG0s display a new form of activism based on pragmatic positioning and technical knowhow, especially in legal matters, all the while testing political boundaries. While such organisations act as a real counterweight within the system whose dysfunctions they seek to correct, their mobilisation is struggling to become institutionalised. They thus reflect the growth of a social form of democracy that helps the authoritarian system adapt, and hence contributes to preserving it.
\end{abstract}

KEY WORDS: Civil society, NG0, migrant workers, labour laws, rights defence movement.

A recent journal article pointed out:

In practice, China already has "two types of workforces and two types of workers' movements." The first is organised within the system under the umbrella of the All China Federation of Trade Unions, and the second operates outside of it, formed spontaneously by workers. The first is institutionalised but lacks a following, and the second has the masses behind it but is not institutionalised.(1)

While these organisations are not all formed by migrant workers themselves (and this is especially so in the Pearl River Delta) but also by an urban elite (lawyers, social workers, and even intellectuals close to the Party) concerned over the conditions of this social category, they in fact seem like semi-union organisations seeking to protect the rights and interests of migrant workers. They help workers file complaints against employers with arbitration committees or courts, and sometimes go to the extent of defending them, organising legal training, negotiating with employers, and putting forward workers' issues to the authorities. NGOs thus act as a substitute to official unions, which have long excluded migrants, (2) and which are increasingly being deemed an ineffective and even illegitimate form of representation.

Although these NGOs act within the framework of state-encouraged "participation," (3) those focusing on defending the rights of "vulnerable categories" (弱势群体), especially workers, operate in sensitive terrain. This is particularly so in recent months, since revolutions in the Arab world stoked the government's fears that they could spread to China. Last January, a propaganda directive banned the use of the term "civil society," (4) which had been widely used for decades in academic journals and the media. What is the nature and impact of these NCOs' mobilisa- tion? Is the government right to fear them? In fact such fear does not seem justified when these organisations' function in the Chinese political system is examined.

A precise and concrete description of NCOs' work in defending migrant workers' rights will show that on the contrary, Chinese social organisations contribute to the political system's flexibility and the regime's dynamic stability, and thus to the Communist Party's ability to remain in power. In fact, NGOs play a major role in defusing social contradictions, in applying and amending laws, and in formulating public policies better suited to workers' needs, as well as administrative reforms that facilitate adaptation of the system and improvement of its effectiveness. In other words, it will be shown that while NGOs defending migrant workers' rights do act as a counterweight, they also contribute to the regime's adaptive capacity and hence to its durability.

Chloé Froissart is Assistant Professor in Chinese studies at Rennes 2 University and Associate Researcher at CNRS-CRAPE (chloefroissart@gmail.com).

1. "Xuezhe jianyan zhongguo zhubu shixian laodong zizhi" (Academic's appeal for a gradual autonomisation of capital-labour relations), Xin Shiji (New Century), 21 June 2011, http://policy.caing.com/ 2011-06-21/100271691.html.

2. It was only in 2003 that the All China Federation of Trade Unions launched a drive to promote migrant workers' membership, thus taking into account the lengthening duration of their stay in cities as well as of the fact that a significant and growing number of those deemed farmers had actually become workers. See Zhonghua quanguo zonggonghui, Guanyu qieshi zuohao weihu jincheng wugong renyuan hefa quanyi gongzuo de tongzhi (ACFTU Directive to resolutely protect migrant workers' legal rights), 4 August 2003, www.people.com.cn.

3. In its Human Rights Action Plan (I, 3), the Party vows to "encourage social organisations to play an active role in enlarging mass participation in expressing their demands, and raise society's self-government capacity; the organisations working for the common good must convey the demands and needs of vulnerable categories." Zhongguo renquan xingdong jihua (2009-2010 nian), http://www.gov.cn/ jrzg/2009-04/13/content_1283983.htm.

4. http://chinadigitaltimes.net/2011/01/latest-directives-from-the-ministry-of-truth-december-152010-january-4-2011/. 


\section{Striving to be non-governmental rather than anti-governmental}

Chinese NGOs face a legal and political framework that precludes autonomous organisations. Principles of control, cooption, and cooperation lie at the heart of laws governing social organisations. In order to register with the Ministry of Civil Affairs or local offices, NCOs have to first find an "umbrella" organisation (in the state or the Party) to serve as guarantor. The guarantor has no legal obligation to endorse the organisation, but is nevertheless responsible for its direction and supervision regarding its programmes, funding, and expenses. It must conduct an annual inspection of the organisation and report to the administration. The guarantor must be from the same field of activity as the NGO, which prevents the latter from diversifying its programmes. Finally, these organisations must not harm "national interests" by going against the constitutional principle of the Party's leading role, or against national unity or "social morality." (5) The law thus stipulates that in order to enjoy official recognition as social organisations, they must, paradoxically, renounce their non-governmental status and act as extensions of the state or at the very least as its auxiliaries.

The law is in reality widely circumvented, as the NGOs jealously guard their independence and official institutions are reluctant to draw attention to practices that could put them on the wrong side of the Party. Moreover, most organisations are not registered, or pass themselves off as enterprises. This compromise helps NGOs enjoy a semi-legal status while preserving their autonomy, with the authorities keeping a wary eye on the organisations. According to Ministry of Civil Affairs figures, there were 425,000 officially registered NGOs in late 2009, (6) but some estimates put the real number at between 3 million and 8 million. ${ }^{(7)}$ Furthermore, these organisations are supposed to pay taxes, but few do so. As a result, tax evasion has become a common pretext for shutting down these organisations when the authorities find them getting too bold. The fact that the government has yet to revise the law on NGOs since its first publication in 1998, despite many appeals for establishing a more rational and liberal legal framework, shows its ambivalence towards them. While these organisations are indispensable to the state, they are nevertheless susceptible to appearing as a threat. Keeping them in a non-institutionalised grey zone allows the authorities to cut them down to size when they are found to be going too far. Judging by developments with regard to the "rights defence movement" in recent years (rising media-fuelled protests among "vulnerable" social categories, academics, jurists, and lawyers focusing on highprofile cases in jurisprudence), relations between the Party and rights defence NGOs have grown more and more tense. The Party is particularly fearful of their potential to trigger a "colour revolution" as in the former Soviet republics, especially as the vast majority of their funding comes from abroad, mainly foundations such as Oxfam Hong Kong, Ford Foundation, World Bank, Canadian and British development funds, US Congress, the embassies of all three countries, and the European Union. NGOs thus evolve in a non-institutionalised grey zone in which their semi-legal status is tolerated so long as they prove useful and loyal to the Party.

These organisations have come up with strategies to deal with their uncertain status. Their discourse seeks to establish a community of interests with the authorities and enterprises: they stress that their action contributes to social stability and supports economic development - in other words, the building of a "harmonious society," to which the Party is wedded. Their main aim is nevertheless to help migrants who work without getting paid, who contract workplace illnesses because their employers have failed to follow laws regarding hygiene and safety, and who are denied medical reimbursement in cases of accidents at work or are refused compensation for infirmity. NGOs remain convinced that the quest for general wellbeing is inseparable from that of the welfare of the maximum number of people, in other words, from the protection of individual rights. ${ }^{(8)}$ They emphasise that strikes resulting from a lack of protection for workers' rights carry major economic costs; that lack of coverage for injured workers plunges entire families into misery, and that such widespread practices are a significant factor of social inequality, especially between the cities and the countryside, which the Party itself has identified as one of the potential causes of destabilisation for the regime. NGOs thus try to find, at least in their discourse, the middle ground where the interests of different parties converge. In other words, these organisations rely on rational and pragmatic argumentation seemingly far removed from any ideological considerations or pronounced political stands. (9) On the contrary, they adopt a purely legalist strategy and invoke central government policies (notably those concerning the protection of migrant workers' rights or the Human Rights Action Plan), the Constitution (notably the 1999 amendments stipulating that the Party "governs according to the law," and those of 2004 affirming that it "respects and preserves human rights"), or the government's own laws and statements, including speeches by Premier Wen Jiabao on the need to promote social justice through greater redistribution and improved access to justice for vulnerable categories. ${ }^{(10)}$ NCOs thus prefer dialogue and cooperation to confrontation, making it clear that they are helping the state and the Party to fulfil functions that they are no longer able to or have yet to take on (thus assuming the role of "state auxiliaries"), with the aim of promoting the ideal of justice the authorities have themselves declared and cannot renounce, as well as developing some programmes in partnership with the authorities. NGOs also try to forge links with influential allies among the authorities in order to acquire viability and legitimacy. Thanks to these strategies, Chinese organisations succeed in achieving a relative autonomy in practice that is denied them by law.

\section{NGO action: Compensating for the system's failings while transforming it from the inside}

NGOs speak of two essential reasons for the lack of protection for migrant workers' rights: a labour law that fails to sufficiently protect workers' interests, and the lack of law enforcement. This is explained by Tong Lihua, a noted Beijing jurist, in the preface to his book Strive for Justice, in which

5. Guowuyuan Bangongting, Minban feiqiye danwei dengji guanli zanxing tiaoli (General Office of the State Council, Provisional rules for registering non-profit social organisations), 25 September 1998, www.goldlaw.com.cn.

6. http:// mca.gov.cn

7. The first estimate is by Wang Ming, Centre for the Development of Civil Society, Tsinghua University; the second by Li Fan, World and China Institute.

8. In this sense, Chinese NGOs do make up a sort of civil society, serving to protect individual rights while affording a social space for organising actions for the common good. Civil society thus operates as a synthesis between the individual and the collective, the particular and the general, the private and the public. See Chen Jianmin, Zouxiang gongmin shehui (Towards a civil society), Hong Kong University Publications, 2010, pp. 3, 11.

9. Thus, as Chen Jianmin points out, both the New Left and the liberals can connect with NGOs, which have basically no political orientation. Chen Jianmin, Zouxiang gongmin shehui, op. cit., p. 3.

10. See, for instance, "Premier vows 'utmost' efforts to redress injustice, says equity brighter than sun," 14 March 2010, http://news.xinhuanet.com/english2010/china/2010-03/14/c_13210331.htm. 
he cites the experience of the NGO he founded, Zhicheng Gongyi (致诚公 益 - Beijing Zhicheng Migrant Workers Legal Aid and Research Centre), which believes in the "application of a public interest law (公益法) constituted in the most realistic and practical manner in order to achieve justice." (11) This is revealing of the mission NCOs have set for themselves: contributing to the amendment of laws to better meet the needs of the poor and the weak - that is to say, the great majority - and participating in their application as well as in systemic reforms that enhance their enforcement. NGOs' mobilisation thus makes up for migrant workers' poor representation in the National People's Congress (NPC), ${ }^{(12)}$ the absence of free trade unions, lack of inspection teams in factories, and the disappearance of mediation committees in the workplace or lack of effective institutions for mediation and arbitration.

\section{Representing workers' interests with the government to amend laws}

NGOs play a crucial role in representing migrant workers' interests to the state, especially in drawing up labour laws to better protect the interests of workers and employees. Their mobilisation takes place in the framework of the "democratic participation" the Party has been promoting in recent years, especially in the form of public consultation on draft laws, which helps the Party design public policies and legislation better attuned to popular aspirations. Chinese NGOs have hastened to fill this breach and come up with recommendation methods inspired by the Western NGOs that fund them. They were most active during the drafting of the new social security law. ${ }^{(13)}$ The draft was put online on 28 December 2008 (opinions were collected until 15 February 2009). Several NGOs discussed the ins and outs of the draft law with migrant workers in meetings and then compiled their thoughts into a common stand.

For instance, the Guangzhou-based NGO Panyu Workers' Service Centre submitted a report synthesising the recommendations of several NGOs in the Pearl River Delta and Hong Kong. They touched on four broad themes: first, promoting equal treatment among citizens, especially between citydwellers and migrants from rural areas. In this context, the report showed that the draft law did not conform to principles it proclaimed, in particular "ensuring that the fruits of growth accrue to all citizens," to the extent that it failed to correct the unequal treatment suffered by migrants in terms of social security. ${ }^{(14)}$ The report stressed that in order for the law to protect all citizens equally, it had to take into account the characteristics of this population, especially the fact that migrants go through several jobs and are highly mobile geographically. The report therefore stressed the need for laws to be applicable everywhere, implying a unification of the systems of social security, mainly between cities and the countryside. This would require recentralising management of social security - currently carried out at the municipal or rural district level - at the national level. The report also drew attention to Article 45 of the Constitution ("Citizens of the People's Republic of China have the right to material assistance from the state and society when they are old, ill, or disabled"). It stressed that the term "citizens" implied that all individuals enjoy equal rights. The draft social security law contravened this constitutional principle by discriminating among workers on the basis of the residence permit (hukou), referring to "urban workers" on the one hand and "rural workers in cities in search of work" on the other. NGOs also favour abolition of the term "workers and employees" (职工), which has an urban connotation. They want it replaced by a neutral term simply standing for all workers (劳动者). The report further stressed that the draft law contravened the Human Rights Action Plan, under which the state committed itself to "abolishing dual structures in society" (15) in accordance with the principle of "human being as the basis" (以人为本), as well as with the principle of equality and justice (公平 与正义) proclaimed by the state and the Party.

Second, NGOs demand a greater engagement by the state and wider redistribution, through such means as the adoption of a substantive social protection system for people whose incomes are less than 40 percent of the average urban salary in their locality. Another major demand is that the state should take total and unconditional charge of work accident victims (hospitalisation and medicine, as well as expenses towards establishing the degree of disability and compensation). (16) Third, NGOs point to the law's restrictive nature, which necessitates the adoption of an effective and independent supervision system, not only of employers but also of the social security system's operating methods - its accounts have to be published, for instance - as well as effective disincentives (legal procedures and stiff penalties). Last, NGOs draw attention to a number of articles, and urge greater clarity for the law so as to forestall misinterpretation in its application or in arbitrations or judgments. In other words, NGOs stress the fact that equality and solidarity are the two principles on which the social security system should be built: coverage has to be widened through greater state participation and the adoption of a national-level management and redistribution system in order to cover the poorest and the most mobile (especially migrants unable to contribute for the durations stipulated in the retirement schemes). ${ }^{(17)}$

Although NGOs were unable to obtain acceptance of the totality of their demands, the law published in late 2010 does incorporate a good number of their suggestions. The new law is a step towards more equal treatment of citizens, noting as it does that it concerns "rural residents working in cities" as well as city dwellers (art. 95). The principle of portability of social

11. Tong Lihua, Weile zhengyi (Strive for Justice), Beijing, Falü chubanshe, 2009, p. 1.

12. Since March 2008, three representatives of migrant workers - coopted for having been chosen as "model workers" by the ACFTU - were allowed to sit on the NPC. This mostly symbolic gesture, coming about within the existing political framework, can hardly go towards promoting real political equality. Migrant workers actually make up 10 percent of China's population but represent less than 1 percent of NPC deputies.

13. Zhonghua renmin gongheguo shehui baoxianfa (Social Insurance Law of the People's Republic of China), adopted on 28 October 2010, took effect on 1 July 2011. http://www.51labour.com/ show/100168.html.

14. Due to the persistence of the population registration system known as hukou inherited from the Maoist era, which grants urban dwellers rights denied to those from rural areas, migrant workers have long been denied social security coverage. Since the early 2000s, municipalities have begun to adopt social security systems for such workers, but they function as insurance based on contributions by employers and employees. They also offer far lower protection than that enjoyed by urbanites in terms of the extent of coverage. Moreover, as social security is managed at the municipal level, migrants lose their rights when they leave the city or the job in which they enjoyed insurance coverage.

15. This is due to the residence permit (hukou), under which only cities have for a long time benefited from a state-run social security system. Since the early 2000 s, a cooperative system has been gradually adopted in the countryside, but the coverage level remains highly uneven between rural and urban areas. There is no link at present between the two systems, which function independently of each other, denying coverage to a migrant who has worked and contributed in the city for many years if he returns to the countryside.

16. This was one of the main issues raised by the NCO Zhicheng Congyi, which fought 152 cases of workrelated accidents between August 2005, when it was set up, and March 2007. In fact, as stated by Tong Lihua, no real protection is gained from current rules stipulating that employers who do not contribute to social security or provide insurance coverage for their employees must put up the entire medical costs of an employee in case of an accident: most employers simply refuse to pay up. With cases tied up for years in futile procedural matters, it is the migrant workers who in fact bear the cost of the accidents they suffer. Tong Lihua, Strive for Justice, op. cit., pp. 221-226.

17. In fact, the draft law stipulates 30 years' contribution in order to draw full retirement benefits, and 15 years for minimum benefits: in practice, this is impossible for most migrant workers. 
security rights was upheld, especially with regard to retirement: the law says that in case an employee is covered in different places during his career, his retirement benefits shall take into account the total contributions made in different localities (art. 19). Consequently, Article 64 envisages a gradual move towards nationwide management of pensions, with management of other insurance schemes gradually being devolved to provinces. However, concrete implementation steps have been left to State Council directives, while the financial contribution of upper-level administrations - especially the central government, which is crucial for unifying different social security systems in cities and the countryside - remains highly fluid. As many NGOs have stressed, the problem is that the law merely states broad principles without getting into feasibility or implementation. It does, however, call for greater state participation in ensuring upfront payment by social security of medical costs entailed by accidents at work. This would help cover medical and hospitalisation costs should the employer refuse to pay, or where responsibility cannot be determined (art. 30). Social security will henceforth also cover the cost of determining the extent of disability, previously left to the victims. However, the law fails to include a proposal for fixing employers' legal responsibility should an enquiry reveal that an accident was caused by the non-observance of work safety legislation. While the law allows greater supervision of social security management through the formation of an experts' committee of lawyers, representatives of the insured, employers, and unions, it fails to include NGOs, despite their suggestion. The committee's independence is carefully restricted, as it answers to the executive and not to the legislature, whereas NGOs had suggested that the committee should be presided over by the head of the People's Congress at the administrative level where the social security system is managed. The distinction between agencies in charge of collecting and disbursing funds has also not been designated. However, as per Article 82, any individual or organisation may file a complaint. As for supervision over employers, the law highlights the role of trade unions, which NGOs had sought to appropriate, as Chinese unions actually fail to take on the task. Penalties, too, fail to measure up as disincentives: firms that do not subscribe to social security for their employees are subject to fines of 500 yuan to 3,000 yuan, but NGOs had demanded 100 times those amounts. They had also recommended that in case of missed contributions or falsified documents, double or treble the amount due be repaid. Finally, the law stresses greater openness: apart from providing for publication of social security accounts and of audits by supervisory committees (art. 80), it also says the insured have to be kept informed of their situation regularly, and that they have a right to free information when they ask for it.

This shows the way in which NGOs rely on the values declared by the Party in order to persuade it to keep its word and wake up to its responsibilities towards workers. Nevertheless, their reasoned arguments have come up against lobbying by Chinese and Western chambers of commerce. The state is likewise inclined to safeguard short-term economic and political interests as well as those of lower administrations. In fact, after a law is passed at the national level, local governments enjoy great latitude over publishing implementation guidelines in line with their resources and "specific conditions." This is why there is a wide chasm, and even real contradictions, between these guidelines and what is proposed through national legislation. NGOs' recommendations therefore target local governments as well, and aim to promote greater compatibility between implementation guidelines and national laws.

\section{Mounting pressure for better application of laws}

NGOs also play an important role in overseeing implementation of laws, making up for Chinese unions' lack of independence and for poorly staffed and inefficient supervision teams in factories. For instance, the Shenzhen Dagongzhe Migrant Worker Centre (深圳打) and six other NCOs, along with students of sociology and social work, carried out three surveys in 2008, 2009, and 2010 on the ways in which firms contravene the new Labour Contract Law, which took effect in January 2008. The survey of three cities in the Pearl River Delta and three more cities in the Yangtze Delta in 2009 featured hundreds of questionnaires and dozens of in-depth interviews. Survey reports showed that a mere 73 percent of workers had signed a contract in 2008 (against 93 percent in official figures). Moreover, most contracts were fraudulent, in English and therefore incomprehensible to employees, incomplete (no address of the firm or job description), or carried the seals of several firms. Almost 60 percent of workers fail to obtain a copy of their labour contract. ${ }^{18)}$ Employers used several stratagems to cut overtime payments, which actually represent half the earnings of migrants. For instance, they kept to a six-day week instead of five days, or made workers sign two contracts, each specifying half of their total salary, with just one taken into consideration. This helped reduce the overtime payment level and other expenses paid by the employer. Moreover, firms tried to make up for salary rises by increasing the price of food or of dormitory lodgings, or by multiplying internal rules, fines, and penalties. This also facilitated the firing of surplus employees over alleged repeated errors, thus evading compensation payments required in the new law (a month's salary for each year served). Fraudulent contracts also complicate action against employers, as some make up false proof with lawyers' help or benefit from the complicity of arbitration committees or courts, which follow internal rules distributed by local governments on how national laws are to be applied. Local authorities have an interest in the firms' profit margins, as they are linked to taxable revenue and as the GDP of their jurisdiction is an important factor in how they are graded by central authorities. In fact, many firms in the Delta pressured authorities during the formulation of the new law, claiming it favoured workers too much, and threatening to move out. The 2010 report thus concludes that it has actually become more difficult for workers to defend their rights under the new law.

NGOs submitted reports denouncing the system's failings and illegal practices to the Ministry of Social Security as well as to the Guangdong provincial authorities, trade unions, and the Shenzhen Municipal Office for Legal Affairs, which have all taken note. They were also shared with several newspapers, which reported them and carried out their own investigations of employers acting in concert to come up with strategies for flouting the law. ${ }^{(19)}$ NGOs cooperate with scholars and the media to inform the public

18. Shenzhen dagongzhe zhongxin (Dagongzhe Migrant Workers Centre), 2008 nian "laodong hetongfa" shichi qingkuang yanjiu (Report of the 2008 survey on application of the Labour Contract Law), unpublished document; Shenzhen dagongzhe zhongxin (Dagongzhe Migrant Workers Centre), 2009 nian "laodong hetongfa" shichi qingkuang yanjiu (Report of the 2009 survey on application of the Labour ContractLaw), unpublished document. For summary in English, see: Shenzhen Dagongzhe Migrant Workers Centre, New ongoing violations after the implementation of labour contract law in China, 12 June 2009, www.workerempowerment.org. Shenzhen dagongzhe zhongxin (Dagongzhe Migrant Workers Centre), Cong "laodong hetongfa" san nian de shichi qingkuang shentao laodongzhe quanli weihu de juxian he kunqing (Reflections on limits to protection of workers' rights based on three years of application of the Labour Contract Law), 2010, unpublished document.

19. See, for instance, "Bang zai laodong hetongfa shang de laozi boyi " (Elaborate chess game since the labour contract law), Nanfang Zhoumo (Southern weekly), 31 July 2008; "Laodong hetongfa bianxingji" (Changes in the contract labour law), Nanfang gongbao (Southern labour news), 2 July 2008; "Bufen zhusanjiao qiye shanzuo "hetong wenzhang" " (Few firms in the Pearl River Delta respect contract labour provisions), Zhongguo jingyingbao (China journal of management), 23 June 2008. 
and higher-level authorities who may not know what happens on the ground, and to raise awareness of the problems. They thus play on the divergence of interests and balance of power among different administrations and hierarchies, while relying on public opinion to pressure the authorities concerned into changing their practices. Such resistance - which basically consists of telling the truth - pushes the limits of what the regime allows, proving also that the press was prevented from following up on the 2009 report. Nevertheless, such mobilisation has borne some fruit: Article 10 of Rules for Promoting Harmonious Labour Relations in the Shenzhen Special Economic Zone, (20) adopted by the Municipal People's Congress on 23 September 2008, specifies that employers must give their employees an approved copy of their contract in Chinese, the same holding true for any revisions. Furthermore, NGOs stress that Article 82 of the Labour Contract Law, stipulating that any firm that has not signed a contract with an employee must pay compensation double the salary, has since then been better respected. (21)

However, NGOs are not content with mobilising merely to expose and denounce the system's failings. They also seek to overcome them in order to better serve workers in the short term while striving to promote changes in the longer term.

\section{Mediation: Cheapest and speediest solution for workers, NGOs, and the state}

Defending rights by following the institutional path is an extremely long and costly process in China. The law gives precedence to arbitration committees in the resolution of labour conflicts. All cases have to be referred to them before going before the courts, which thus serve as appeal courts. (22) Apart from the fact that arbitration committees often refuse to take up cases, such as when proof of a labour relation is lacking, ${ }^{(23)}$ and thus block all paths to institutional resolution of the conflict, they are also notoriously ineffective. Figures from the Beijing Legal Aid Office for Migrant Workers show that of the 466 cases handled by the city's arbitration committees over a two-year period, a mere 2.6 percent were satisfactorily resolved. (24) The procedures are also extremely long: according to the Rules on Government Insurance for Work Related Accidents, ${ }^{(25)}$ compensation may take from three years and nine months to six years and seven months. In fact, the delay and costs are even greater. A case in point is the experience of a team of 68 construction workers defended by Zhicheng Gongyi. In claiming 33,000 yuan in unpaid wages, the workers' leader had to make some 20 trips between his native Hebei and Beijing. He went 14 times for work inspection, and 14 more times to courts, apart from contacting nine different institutions such as the municipal construction committee and the Ministry of Labour and Social Security. During the three years it took to claim his team's wages, the migrant worker spent more than 5,000 yuan on transport, accommodation, food, telephone calls, and office expenses. In the meantime, he had to stop full-time work to focus entirely on his mission. The total cost of recovering 33,000 yuan of unpaid wages was estimated at 13,000 yuan by the NGO, which moreover bore the cost of fighting the case. ${ }^{26)}$ Zhicheng Gongyi thus demonstrated that the cost of defending rights is very high for migrant workers, the state, and society (in terms of taxes). A 2005 survey of 8,000 migrant workers in eight provinces showed that in order to claim 1,000 yuan in wages, one has to spend at least 920 yuan and devote 11 to 21 days, which equates to a loss of between 550 yuan and 1,050 yuan in wages. The state's expenses (staff salaries) amount to at least 1,950 yuan to
3,750 yuan. As for legal aid, often furnished by NGOs, it amounts to between 3,420 yuan and 5,720 yuan. (27) This explains NGOs' and migrant workers' preference for mediation. NCOs do enjoy some influence in negotiating with employers, if they have strong governmental backing. In reality that is true of few organisations. Zhicheng Gongyi might be among them, to the extent that this NCO - registered with the Ministry of Civil Affairs - has always focused on winning the authorities' trust by relying on dialogue and cooperation at all levels of officialdom, including the central authorities. (28) Moreover, its founder holds several honorary posts: he serves on the standing committee of the All China Lawyers Association, of which he is vice-president, and he is also with the Communist Youth League in Beijing's Fengtai District. Similarly, in August 2004, Beijing-based NGO Xiaoxiaoniao (Little Bird) formed the first mediation committee managed non-officially in collaboration with the Legal Affairs Bureau of Beijing's Dongcheng District.

NGOs are thus replacing mediation committees that existed in state enterprises but have disappeared, making up for unions' impotence and assisting municipal institutions (labour and social security offices or justice bureaus) that are no longer able to handle the flood of complaints. But as the functions performed by the state are gradually assumed by NGOs, and with greater efficiency, this does not augur well for the genuine and lasting systemic changes that so many of them earnestly seek.

\section{Promoting high-profile cases to create a precedent}

Some NGOs also focus on fighting high-profile cases, most often collective, while developing campaigns to plead with authorities in cooperation with the media in hopes of creating jurisprudence. This was so in the case of Xu Yan'ge (徐延格) in 2006: the case was fought by Zhicheng Gongyi, obliging Kentucky Fried Chicken (KFC) to terminate a practice known as "dispatch labour" that contravened an interim provision that was to be well codified in the Contract Labour Law that was under preparation while the case was in progress. Such workers, often employed by foreign firms and multinationals in China, are obliged to sign a job contract with a small company that undertakes to pay their salaries and contribute to social security, whereas in fact those workers continue to work for the main enterprise. This practice makes it easy for the actual employers to fire workers when they are no longer needed, thus greatly reducing compensations paid out. ${ }^{(29)}$ This

20. Shenzhen jingji tequ hexie laodong guanxi cujin tiaoli, http://www.npc.gov.cn/npc/xinwen/dfrd/ guangdong/ 2008-10/08/content_1452415.htm.

21. Apart from NCO action, this improvement was no doubt also due to the end of the economic crisis.

22. See, for instance, Guowuyuan, Gongshang baoxian tiaoli (State Council, Rules governing insurance for work related accidents), 16 April 2003, http://www.gov.cn/zwgk/2005-05/20/content_144.htm.

23. This is often the case, for instance, in the construction sector, where the relationship between workers and their baogongtou (包工头) is not subject to a work contract. The baogongtou is a sort of overseer, often from the same village as his fellow workers, acting as a link between them and the construction firm of which he is a sub-contractor and the only one with a legal working relationship with it. See Pun Ngai's article in this issue.

24. Tong Lihua, Weile zhengyi, op. cit., p. 218.

25. Gongshang baoxian tiaoli, op. cit.

26. Ibid., p. 216.

27. Ibid., p. 22.

28. It enjoys the backing of the Ministry of Justice's Legal Aid Centre, national and Beijing city Foundations for Legal Aid, and the national and Beijing Communist Youth Leagues, as well as of the People's Congress and government of Beijing's Fengtai District where its office is located.

29. The problem arises from the imprecise understanding of the interim arrangement in the legislation: "worker's transfer from one enterprise to another" (laowu paiqian 劳务派遣). Although the labour law specifies that such transfers should be aimed at reducing joblessness by creating new temporary jobs - which corresponds to the definition of an intermediary firm recruiting workers on behalf of those where they work temporarily - the law was vague enough to allow the practice in reverse. 
was in fact Xu Yan'ge's experience; he was fired after working for KFC for 11 years without a proper contract. He had, however, signed a contract with a cover agency for a year and five months, which meant the US multinational paid him compensation of 3,660 yuan instead of the 20,130 yuan he ought to have received given his 11 years' service. The arbitration committee rejected Xu's complaint, citing the absence of a work contract with KFC, even though Xu furnished other proofs attesting to his work relationship with the US chain. Another 28 KFC employees faced the same fate but preferred not to pursue legal claims for fear of losing their jobs. In fact, according to Zhicheng Gongyi, tens of thousands of workers have fallen victim to this practice in China. ${ }^{(30)}$

The challenge was all the greater as the new Labour Contract Law was being discussed, and there was a possibility of the legislation being amended following public debate, or being accepted as it was, the European and American chambers of commerce having spread the word that foreign firms would pull out of China if the Labour Contract Law were to curb the practice of dispatch labour. Reacting to this offensive, publications such as China Youth Daily and Southern Metropolis News carried articles explaining how foreign firms made illegal use of laowu paiqian. They specifically criticised KFC, explaining the Xu Yan'ge case. (31) Meanwhile, the ACFTU accused KFC through the China Economic Review of applying human rights double standards by using the dispatch labour practice exclusively for Chinese migrant workers. ${ }^{(32)}$ The press thus became the arena of confrontation for experts (lawyers, academics), unions, and NGOs on the one hand, and KFC and the foreign chambers of commerce on the other. Debate spilled over online, where public opinion overwhelmingly favoured $X u$ and called for scrapping the dispatch labour practice. The first court appearance was a failure: Xu's plea was rejected on the basis of the contract he had signed with another firm. KFC then put out an open letter carried by the press, claiming that its practice was in conformity with Chinese law. Zhicheng Gongyi then mounted a defence by carrying out its own enquiries, tapping expert opinion as well as contacting a senior ACFTU official. Zhicheng Gongyi drafted a report based on a strictly legal argumentation, refuting point by point all of KFC's arguments before the court, and showing that $\mathrm{Xu}$ had been compelled to sign a contract with a cover agency. This contract was thus null and void, and KFC's practice did not amount to "workforce transfer," inasmuch as Xu continued to work for the US chain, and illegally at that, since he was denied a proper contract. Xu was moreover fired over a minor fault, which occurred after he had put in overtime well above the legally authorised quota. Zhicheng Gongyi's report also showed that "workforce transfer" amounts to "dispatch labour," that is, its purpose is to allow one firm to escape its social responsibilities and is thus legally unsustainable. The agency with which Xu had signed the contract lacked the means to assume its social responsibilities, and as such, the case was emblematic of the misuse of "workforce transfer" when "dispatch labour" is meant. The report's last part stressed that Xu's case was hardly unique, and that a considerable number of other Chinese workers were affected by this practice. It noted the context in which it developed and pointed to the offensives mounted by foreign chambers of commerce in China, which were trying to safeguard their interests at the cost of Chinese workers' fundamental rights. The report also explained the reasons for Xu losing the case by pointing to lacunae in the law. Zhicheng Gongyi then called a press conference, following which several newspapers published the conclusions of its report. A few days later, KFC officially acknowledged its mistakes and ended the dispatch labour practice. Xu was compensated in return for abandoning plans to file an appeal. Finally, the Labour Contract Law eventually included 11 articles (57 to 67) codifying the workforce transfer practice. It stipulates that such transfer must take place with the worker's assent, that the firm where the worker is sent must have a minimum capital of 500,000 yuan and set aside a reserve fund, and that in case of problems such as workplace accidents, the responsibility falls on both firms. The law also specified that the practice of transfer should only concern temporary workers for a maximum of two years, and that an employee cannot be transferred again to another post. Although the "dispatch labour" practice has not been abolished in name, it has become clearly codified in favour of workers, except on one count: the calculation of seniority. This issue was not tackled, the possibility of creating jurisprudence on this point having been lost with the amicable settlement of Xu's case and abandonment of his plans to appeal. This is highly regretted by Zhicheng Gongyi, which has stressed that the law's silence on this issue has in a way allowed the practice to continue: the NGO has had to fight many cases similar to Xu's since then. ${ }^{(33)}$ In fact, a recent ACFTU survey has revealed that the practice has proliferated in recent years and affects 60 million Chinese workers. Their period of employment varies from two to ten years; the temporary character of such jobs as stipulated by law is thus flouted. (34) Zhicheng Congyi underlines that only the principle of firms' responsibility for workplace accidents and the prohibition of enterprises "dispatching" the same employee several times are respected. But the dispatch labour practice in fact allows for the payment of different salaries for the same work, migrant workers being the main victims of the phenomenon. ${ }^{(35)}$

Such mobilisation seems to be a good illustration of what Kevin O'Brien and Li Lianjiang call "rightful resistance": a resistance that operates at the limits of institutional channels, combining legal or administrative action with political pressure (mobilising the media, allying with influential personalities within the system), and referring to officially endorsed values to operate within the framework of such values and in tension with them. ${ }^{(36)}$ NGOs thus take the Party at its word and appeal to it as if human rights were its ultimate reference point and intangible value (假戏真唱). This example shows also that such resistance is struggling to become institutionalised: while the $\mathrm{Xu}$ case was resolved and some peripheral legal guaranties accrued, the real aim of such mobilisation - affording all workers in such cases the possibility of obtaining reparations and preventing recurrence of such practices - has not been realised. From the political decision-making

30. Another problem linked to this practice is that cover agencies are usually small and precarious. Some fail to contribute to employees' social security and are unable to meet hospitalisation costs in case of accidents at work.

31. See, for example, "Kendeji citui 11 nian laoyuangong, jujue chengren cunzai laodong guanxi " (KFC fires employee with 11 years' experience and refuses to admit he worked for it), Zhongguo qingnianbao (China Youth Daily), 13 May 2006; "Kendeji beisu 'fanlian bu renren' - lianxu gongzuo le 11 nian Kendeji fouren shi qi yuangong " (KFC accused of turning on its own - firm refuses to admit an employee had worked for it for 11 consecutive years), Beijing qingnianbao (Beijing Youth Daily), 15 May 2005; "Kugan 11 nian bei citui, yin wei jian laodong hetong taoxin zaoju" (A worker is fired after 11 years' hard work but cannot get his due as he lacked a work contract), Nanfang Dushibao (Southern Metropolis News), 14 May 2006.

32. "Quanzong guanyuan piping qiye: laodong yonggong gao shuang zhong biaozhun" (ACFTU official attacks firm's double standards towards its workers), Zhongguo Jingji Zhoukan (China Economic Review), 5 June 2006.

33. Tong Lihua, Weile zhengyi, op. cit., pp. 366-396.

34. Pan Yi (Pun Ngai), Deng Yunxue, "Laowu paiqian zhidu jinxing shi" (When the reform of the delegation system is adopted), Nanfang chuang, 10 April 2011, http://www.nfcmag.com/articles/2744.

35. Interview with the NCO's lawyers, July 2011.

36. Kevin J. O'Brien, Lianjiang Li, Rightful Resistance in Rural China, Cambridge, Cambridge University Press, 2006. 


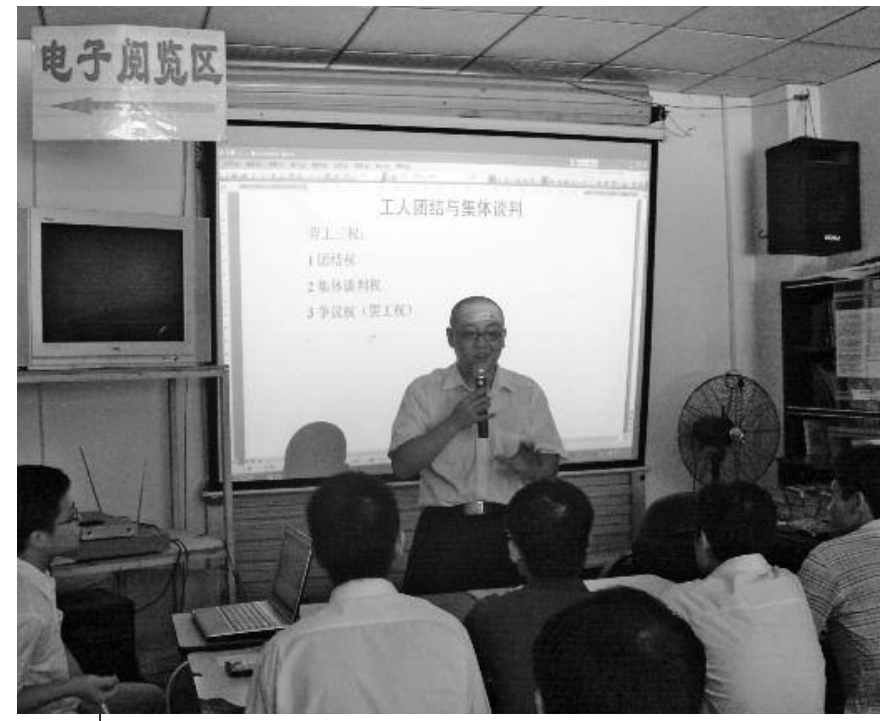

Training session on collective negotiations at an NGO in southern China. @ Chloé Froissart

perspective, pragmatic considerations and economic interests have prevailed over legal and ethical ones: in this sense, it is possible to speak of a victory for the foreign chambers of commerce. Moreover, some legal guaranties won on paper are not applied. As NGOs themselves admit, the impact of their mobilisation remains limited, and they must always be ready to remobilise anew. Meanwhile, such mobilisation has longer-term consequences, but more social than political: it has helped workers become better informed about the practice of dispatch labour and its effect on their rights. NGO action has also sparked a debate on the norms that society needs to foster.

\section{Prevention rather than cure: promoting collective negotiations}

Given these constraints, many NGOs - in the Pearl River Delta especially - prefer working on preventive measures, on shifting the power balance at workplaces by training workers to negotiate more effectively with their bosses. They have conducted workshops where migrants become familiar with various laws, come to see legislation as self-defence weapons, and assert their rights. Participants have become aware of the chasm between what the law says and their own situation; they are encouraged to identify causes for this (the absence of independent unions, of the right to strike, and of the possibility of organising themselves autonomously). Such workshops do not focus on legal education alone, but also seek to boost workers' self-confidence, analyse the balance of power within factories, hammer out a collective identity, and see what can be done within the prevailing system. NGOs thus help workers become aware of their rights (which is different from just getting to know the law) and assist them in developing their bargaining skills. In fact, NGOs claim that more and more migrant workers have acquired the skills to negotiate directly with their bosses.

Some cadres and employers are not necessarily hostile to such bargaining, or even to correcting the power balance within the workplace, to the extent that such measures help avoid work stoppages, strikes, and other disturbances that benefit none of the parties concerned. Social dialogue between NGOs and authorities has also helped push laws in this direction over the past few years. ${ }^{(37)}$ While the Party has thus far emphasised consultation with workers and not their active participation in decision-making within enterprises, Shenzhen municipality's April 2008 guidelines for applying the Law on Unions ${ }^{(38)}$ for the first time replaced the term "collective consultations" (集体协商) with "collective bargaining" (集体谈判), specifying that workers, unions, and employers must have recourse to it in order to prevent and resolve conflicts. After last year's widespread strikes, a pilot study to draw up rules for democratic management of firms in Guangdong, (39) published in August 2010, set out procedures for the formation of employees' representations, clearly defining its powers. It stipulated that an employer is obliged to enter into collective bargaining on wages if a third of the workforce wants it. If the employer fails to respond within 15 days and a strike breaks out, those taking part in it cannot be fired. If implemented, these rules would constitute a major step towards institutionalising the right to strike. Negotiations over their adoption have been stalled for now, mainly due to opposition from Hong Kong-based firms. A pilot project on rules for collective bargaining in Shenzhen, ${ }^{(40)}$ published in August 2010, sought to limit the discretionary powers of employers, who could face a fine of 50,000 yuan if they did not deliver on what was decided during negotiations. Finally, the revision of the law on unions this year should lead to greater collective bargaining at the level of broad industrial sectors and not only within individual factories.

Although for the Party, worker participation is only conceivable within the framework of the official unions, the current socio-economic and political logic suggests that a formula giving greater autonomy to workers will have to be found in the not too distant future. First, since the 20072008 economic crisis, the Chinese government has preferred Keynesian policies aimed at stimulating domestic demand and reducing dependence on external factors. But how is domestic demand to be stimulated without boosting social security and salaries? Also, how to do so without strengthening workers' bargaining power? Second, as Jean-Philippe Béja points out in this issue, although last year's strikes failed to constitute a sustained social movement, the authorities know such a movement could erupt at any time. Workers thus demonstrated a greatly enhanced ability to mobilise and organise. Finally, as highlighted above, arbitration committees and courts are already overworked and can no longer take on the flood of complaints, while the cost of institutional handling of conflicts is also extremely high for the state and society. As is the custom in China, it is possible that collective bargaining with "Chinese characteristics" will emerge when the costs of the current situation proves too great for the Party.

37. NGOs have not been alone in clamouring for independent workers' organisations and for real collective bargaining. Academics such as Chen Kai - who helped resolve the conflict at a Honda unit last year - also support such stands. See "Xuezhe jianyan zhongguo zhubu shixian laodong zizhi" (Academic pleads for gradual moves towards autonomous capital-labour relations), Xin Shiji (New Century), 21 June 2011, http://policy.caing.com/2011-06-21/100271691.html.

38. Shenzhen shi shichi "Zhonghua renmin gongheguo gonghuifa" banfa (Application of the Law on Unions in Shenzhen), 1 April 2008, http://law-star.com/cacnew/200807/180020962.htm.

39. Guangdongsheng renli ziyuan he shehui baozhang ting, Guangdongsheng qiye minzhu guanli tiaoli (Guangdong provincial office of human resources and social security, Rules for democratic management of enterprises), 6 August 2010, http://law.51labour.com/lawshow-90971.html.

40. Shenzhenshi renda changweihui bangongting, Shenzhen jingji tequ tjti xieshang tiaoli (Office of the Shenzhen municipal people's congress standing committee, Regulations for collective negotiations in Shenzhen Special Economic Zone), 13 August 2010, http://law.51labour.com/lawshow-91037.html. 


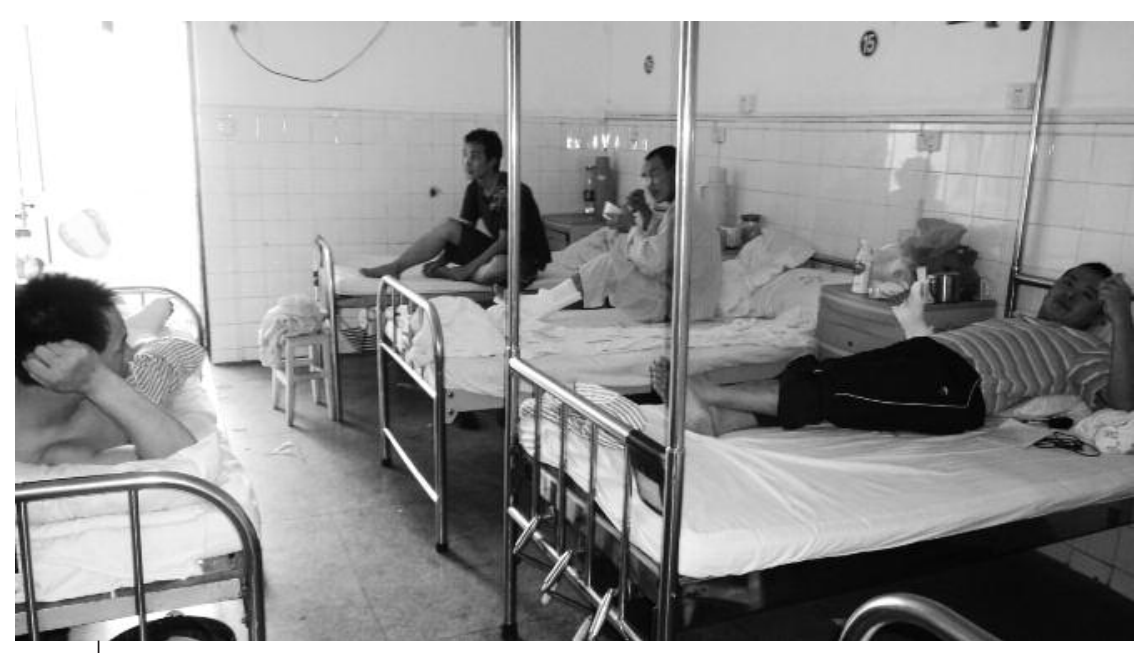

Victims of workplace accidents at a hospital in Southern China. NGOs visit them to inform them of their rights and to help them file complaints against employers. $\odot$ Chloé Froissart

\section{What political implications?}

NGOs rely on the Party's declared values, claiming to take them seriously so as to be able to apply democratic pressure and compel the Party to remain engaged in protecting individual rights and the common good. They have organised an array of measures for surveillance, obstruction, and judgment, through which they apply corrective power and pressure aimed at obliging the state and the Party to better assume their own responsibilities. They thus seek to alleviate the authoritarian system's dysfunction and to promote change from the inside so as to ensure lasting protection of citizen's rights. However, it is difficult for NGO actions to achieve institutionalisation, and they are only able to effect slight corrections in the balance of power in favour of the weakest and the most impoverished, at the cost of tremendous efforts and an unfailing devotion to the cause. In this sense, NGOs constitute a counterweight within the system, playing an integral role in the regime's dynamic stability and contributing to keeping the Party in power. In fact, although they represent an attempt to organise in defiance of the Party, NGOs also confirm its attributions by representing the concerns of the powerless to the Party, rather than against the Party. Thus their mobilisation results in slight legal amendments and ad hoc adjustments at the margins of the system. However, this has little consequence in the political, institutional sphere. NGOs act as a means of venting popular discontent in as much as the poor and the weak find it difficult to gain access to the state and Party leadership. They thus ensure a meaningful mobilisation for those taking part, create a sense of social commonality, and find practical solutions for cases of injustice. NGOs thus prevent the migrant workers they serve from resorting to lawless acts (public threats of suicide, which often end in loss of life or crimes against employers) that could add to the acts of desperation Chinese society is increasingly witnessing. ${ }^{(41)}$ To this one can reply that NGOs' actions are not unidirectional, and that by raising human rights awareness among workers, they indirectly contribute to boosting collective action. However, despite the fact that these collective actions, although radicalised in recent years, do not yet constitute a social movement, ${ }^{(42)}$ they exert much-needed pressure for the system to continue adapting, especially the unions, and for minimum social standards to continue increasing. In other words, this social mobilisation leads to a power adjustment needed for the dynamics of change underlying the regime's adaptation.

To the extent that they provide an outlet for social tensions and channel them in constructive struggles fostering slight corrections of inequality and peripheral systemic changes, NGOs ensure the authoritarian Chinese regime's flexibility. They apply pressures needed for the regime's adaptation and durability. In this sense, they form an integral part of its functioning and its dynamic of adaptation.

\section{Translated by N. Jayaram}

41. The Yang Jia case in 2008, serial killings in schools last year, or the more recent case of a man who blew himself up in front of a court in Yunnan, are some major examples of such acts.

42. See Jean-Philippe Béja's article in this issue. 